\title{
FILSAFAT PENDIDIKAN KI HADJAR DEWANTARA DAN SUMBANGANNYA BAGI PENDIDIKAN INDONESIA
}

\section{Henricus Suparlan}

Fakultas Psikologi, Universitas Sarjanawiyata Tamansiswa

Email: na26tia@gmail.com

\section{Abstrak}

Globalisasi yang dipengaruhi oleh kepentingan pasar telah mengakibatkan pendidikan tidak sepenuhnya dipandang sebagai upaya mencerdaskan kehidupan bangsa dan proses pemerdekaan manusia, tetapi mulai bergeser menuju pendidikan sebagai komoditas. Untuk menangkal model pendidikan sebagai komoditas maka konsep pendidikan Ki Hadjar Dewantara ditawarkan sebagai solusi terhadap distorsi-distorsi pelaksanaan pendidikan di Indonesia dewasa ini. Menurut Ki Hadjar Dewantara, hakikat pendidikan adalah sebagai usaha untuk menginternalisasikan nilai-nilai budaya ke dalam diri anak, sehingga anak menjadi manusia yang utuh baik jiwa dan rohaninya. Filsafat pendidikan Ki Hadjar Dewantara disebut dengan filsafat pendidikan among yang di dalamnya merupakan konvergensi dari filsafat progresivisme tentang kemampuan kodrati anak untuk mengatasi persoalan-persoalan yang dihadapi dengan memberikan kebebasan berpikir seluas-luasnya, dipadukan dengan pemikiran esensialisme yang memegang teguh kebudayaan yang sudah teruji selama ini. Dalam hal ini Ki Hadjar Dewantara menggunakan kebudayaan asli Indonesia sedangkan nilai-nilai dari Barat diambil secara selektif adaptatif sesuai dengan teori trikon (kontinyuitas, konvergen dan konsentris). Tiga kontribusi filsafat pendidikan Ki Hadjar Dewantara terhadap pendidikan Indonesia adalah penerapan trilogi kepemimpinan dalam pendidikan, tri pusat pendidikan dan sistem paguron.

Kata kunci : progresivisme, esensialisme, among.

\section{Abstract}

Globalization is influenced by fundamentalist spirit of the market has resulted in education is not fully regarded as an effort to educate the nation and the liberation of man, but began to shift toward education as a commodity. To counteract this kind of educational model, the concepts of Ki Hadjar Dewantara education is offered as a solution to the distortions implementation of education in Indonesia today. According to Ki Hadjar Dewantara, the essence of education is to incorporate culture in the child, and put the child into the culture so that children become human beings. Educational philosophy Ki Hadjar Dewantara 
Among these so-called philosophy of education in which the convergence of the philosophy of progressivism about the child's natural ability to resolve the problems faced by giving the widest freedom of thought, but it also uses culture that has stood the test of time, according to essentialism, as the basic education of the child to achieve his goal. In this case Ki Hadjar Dewantara using native Indonesian culture while the values of the West are taken in accordance with the theory of selective adaptative Trikon (continuity, convergent and concentric). Three contributions of Ki Hadjar Dewantara's educational philosophy for the Indonesian education are the application of a trilogy of leadership in education, three centers of education and the paguron system.

Keywords: progressivism, essentialism, Among.

\section{PENDAHULUAN}

Globalisasi yang dipengaruhi oleh kepentingan pasar menyebabkan pendidikan tidak sepenuhnya dipandang sebagai upaya mencerdaskan bangsa dan proses pemerdekaan manusia tetapi mulai bergeser menuju pendidikan sebagai komoditas (Saksono, 2010: 76). Pengaruh globalisasi yang sedang dan akan berlangsung akan berpengaruh terus-menerus sampai waktu yang tidak ditentukan dan ini semakin sulit untuk diatasi. Melihat kemungkinan-kemungkinan yang akan terjadi pada masa-masa yang akan datang, rasanya sangat berat sehingga bangsa Indonesia harus secara serius menangani masalah ini.

Globalisasi telah mengakibatkan pergeseran tujuan pendidikan nasional dari tingkat dasar sampai tingkat tinggi yang tidak lagi hanya untuk mencerdaskan kehidupan bangsa, tetapi lebih berfokus untuk menghasilkan lulusan yang menguasai scientia. Dengan penguasaan scientia dinilai mengarahkan peserta didik kepada hasil yang bersifat pragmatis dan materialis, karena kurang membekali peserta didiknya dengan semangat kebangsaan, semangat keadilan sosial, serta sifatsifat kemanusiaan dan moral luhur sebagai warga negara (Saksono, 2010: 76). Bangsa Indonesia saat ini dihadapkan pada krisis karakter yang cukup memprihatinkan. Demoralisasi mulai merambah di dunia pendidikan seperti ketidakjujuran, ketidakmampuan mengendalikan diri, kurangnya tanggung jawab sosial, hilangnya sikap ramah-tamah dan sopan santun (Sutiyono dalam Jurnal Cakrawala Pendidikan, 2010: $42)$. 
Untuk menangkal model pendidikan semacam itu maka konsep pendidikan Ki Hadjar Dewantara ditawarkan sebagai solusi terhadap distorsi-distorsi pelaksanaan pendidikan di Indonesia dewasa ini. Ki Hadjar Dewantara mengatakan hendaknya usaha kemajuan ditempuh melalui petunjuk "trikon", yaitu kontinyu dengan alam masyarakat Indonesia sendiri, konvergen dengan alam luar, dan akhirnya bersatu dengan alam universal, dalam persatuan yang konsentris yaitu bersatu namun tetap mempunyai kepribadian sendiri (Dewantara, 1994:371).

Pestalozzi, Frobel dan Maria Montessori adalah tokoh-tokoh pendidikan yang berpengaruh pada Ki Hadjar dalam menggunakan kebudayaan di dalam kurikulum pendidikan. Mulai dari TK (Taman Kanakkanak/Taman Indria) sampai sekolah menengah unsur-unsur kebudayaan lokal dimasukkan dalam kurikulum untuk melatih panca indera jasmani, kecerdasan dan utamanya adalah kehalusan budi pekerti. Pelajaran yang diberikan di Taman Indria mulai dari dolanan anak, mendongeng, hingga sariswara yaitu menggabungkan antara lagu, cerita dan sastra. Nilai-nilai budaya ini dimaksudkan untuk mendidik rasa, pikiran dan budi pekerti. Anak-anak yang sudah agak besar, misalnya di Sekolah Menengah Pertama (Taman Dewasa) dan Sekolah Menengah Atas (Sekolah Menengah Madya), diberikan pelajaran olah gendhing.

Ki Hadjar Dewantara mengatakan bahwa olah gendhing dan seni tari adalah untuk memperkuat dan memperdalam rasa kebangsaan (Dewantara, 2011:344). Tari Bedoyo dan Tari Serimpi diberikan kepada anak didik karena merupakan kesenian yang amat indah yang mengandung rasa kebatinan, rasa kesucian, dan rasa keindahan.

Berdasarkan pada uraian di atas maka artikel ini secara khusus akan membahas beberapa permasalahan, yaitu: (a) Apa hakikat pendidikan menurut Ki Hadjar Dewantara?; (b) Apa filsafat pendidikan Ki Hadjar Dewantara?; dan (c) Apa sumbangan pemikiran Ki Hadjar Dewantara bagi pelaksanaan pendidikan Indonesia? 


\section{KONSEPSI PENDIDIKAN KI HADJAR DEWANTARA DALAM TINJAUAN FILSAFAT PENDIDIKAN}

Ki Hadjar Dewantara mengajukan beberapa konsep pendidikan untuk mewujudkan tercapainya tujuan pendidikan, yaitu Tri Pusat Pendidikan: (1) pendidikan keluarga; (2) pendidikan dalam alam perguruan; dan (3) pendidikan dalam alam pemuda atau masyarakat.

Ki Hadjar Dewantara memasukkan kebudayaan dalam diri anak dan memasukkan diri anak ke dalam kebudayaan mulai sejak dini, yaitu Taman Indria (balita). Konsep belajar ini adalah Tri No, yaitu nonton, niteni dan nirokke. Nonton (cognitive), nonton di sini adalah secara pasif dengan segenap panca indera. Niteni (affective) adalah menandai, mempelajari, mencermati apa yang ditangkap panca indera, dan nirokke (psychomotoric) yaitu menirukan yang positif untuk bekal menghadapi perkembangan anak (Dwiarso, 2010:1).

Ketika anak didik sudah menginjak pada pendidikan Taman Muda (Sekolah Dasar), kemudian Taman Dewasa dan seterusnya maka konsep pendidikan Ki Hadjar Dewantara adalah Ngerti, Ngroso lan Nglakoni. Model pendidikan ini dimaksudkan supaya anak tidak hanya dididik intelektualnya saja (cognitive), istilah Ki Hadjar Dewantara 'ngerti', melainkan harus ada keseimbangan dengan ngroso (affective) serta nglakoni (psychomotoric). Dengan demikian diharapkan setelah anak menjalani proses belajar mengajar dapat mengerti dengan akalnya, memahami dengan perasaannya, dan dapat menjalankan atau melaksanakan pengetahuan yang sudah didapat dalam kehidupan masyarakat.

Sebagai bagian akhir dari hasil pendidikan, menurut Ki Hadjar Dewantara, adalah menghasilkan manusia yang tangguh dalam kehidupan masyarakat. Manusia yang dimaksud adalah manusia yang bermoral Taman Siswa, yaitu mampu melaksanakan Tri Pantangan yang meliputi tidak menyalahgunakan kewenangan atau kekuasaan, tidak melakukan manipulasi keuangan dan tidak melanggar kesusilaan (Ki Suratman, 1987:13). 


\section{KONSEPSI PENDIDIKAN KI HADJAR DEWANTARA DALAM TINJAUAN FILSAFAT PENDIDIKAN PROGRESIVISME}

Progresivisme mempunyai konsep yang didasari oleh pengetahuan dan kepercayaan bahwa manusia itu mempunyai kemampuankemampuan yang wajar dan dapat menghadapi dan mengatasi masalah-masalah yang bersifat menekan atau mengancam adanya manusia itu sendiri. Berhubung dengan itu progresivisme kurang menyetujui adanya pendidikan yang bercorak otoriter, baik yang timbul pada jaman dahulu maupun pada jaman sekarang (Barnadib, 1982: 28). Berikut adalah penjelasan konsep-konsep pendidikan Ki Hadjar Dewantara dalam perspektif Progresivisme.

\section{Konsep Ki Hadjar Dewantara tentang pendidikan}

Konsep Ki Hadjar Dewantara pada sistem among mengatakan bahwa sistem among yang berjiwa kekeluargaan bersendikan 2 dasar, yaitu: pertama, kodrat alam sebagai syarat kemajuan dengan secepatcepatnya dan sebaik-baiknya; kedua, kemerdekaan sebagai syarat menghidupkan dan menggerakkan kekuatan lahir dan batin anak agar dapat memiliki pribadi yang kuat dan dapat berpikir serta bertindak merdeka.

Pada bagian lain dikatakan bahwa kodrat alam merupakan batas perkembangan potensi kodrati anak didik dalam proses perkembangan kepribadiannya. Perkembangan yang sesuai dengan kodrat alam akan berjalan lancar dan wajar karena pada hakikatnya manusia adalah makhluk yang menjadi satu dengan kodrat alam. Manusia atau anak tidak bisa lepas dari kehendak-Nya, tetapi akan bahagia jika dapat menyatukan diri dengan kodrat alam yang mengandung kemajuan. Kemajuan tersebut seperti bertumbuhnya tiap-tiap benih suatu pohon yang kemudian berkembang menjadi besar dan akhirnya hidup dengan keyakinan bahwa dharma-nya akan dibawa hidup terus dengan tumbuhnya lagi benih-benih yang disebarkan.

Sejalan dengan konsep pendidikan Ki Hadjar Dewantara atas dasar kodrat alam, maka filsafat pendidikan progresivisme mengata- 
kan atas dasar pengetahuan dan kepercayaan bahwa manusia itu mempunyai kemampuan-kemampuan yang wajar dan dapat menghadapi serta mengatasi masalah yang bersifat menekan atau mengancam manusia itu sendiri. Oleh karena itu antara Ki Hadjar Dewantara dengan filsafat progresivisme sama-sama menentang pendidikan yang bercorak otoriter, karena hal itu akan menyebabkan kesulitan dalam pencapaian tujuan pendidikan.

Konsep Ki Hadjar selanjutnya adalah dasar kemerdekaan yang mengandung pengertian bahwa hal itu sebagai karunia Tuhan Yang Maha Esa kepada manusia dengan memberikan hak untuk mengatur dirinya sendiri (zelfbeschikkingsrecht) dengan mengingat syarat tertib damainya (orde en vrede) hidup masyarakat. Menurut Priyo Dwiarso, siswa harus memiliki jiwa merdeka, dalam arti merdeka lahir, batin serta tenaganya. Jiwa merdeka ini sangat diperlukan sepanjang jaman agar bangsa Indonesia tidak didikte negara lain. Sistem among melarang adanya hukuman dan paksaan kepada anak didik karena akan mematikan jiwa merdekanya, mematikan kreativitasnya (Dwiarso, 2010: 6).

Konsep jiwa merdeka ini selaras dengan filsafat progresivisme terhadap kebebasan untuk berpikir bagi anak didik, karena merupakan motor penggerak dalam usahanya untuk mengalami kemajuan secara progresif. Anak didik diberikan kebebasan berpikir guna mengembangkan bakat, kreatifitas dan kemampuan yang ada dalam dirinya agar tidak terhambat oleh orang lain.

Menurut Ki Hadjar Dewantara, pendidikan adalah usaha kebudayaan yang bermaksud memberikan bimbingan dalam hidup tumbuhnya jiwa raga anak didik agar dalam garis-garis kodrat pribadinya serta pengaruh-pengaruh lingkungan, mendapat kemajuan hidup lahir batin (Ki Suratman, 1987: 11). Kebudayaan adalah buah budi manusia sebagai hasil perjuangannya terhadap pengaruh alam dan jaman atau kodrat dan masyarakat. Budi adalah jiwa yang sudah matang, sudah cerdas, oleh karena itu dengan kebudayaan, budi manusia dapat mencapai 2 sifat istimewa yaitu luhur dan halus, dengan demikian maka segala ciptaan budi senantiasa mempunyai sifat luhur dan halus 
juga. Jadi kebudayaan merupakan suatu proses perkembangan secara dinamis mengenai kemenangan perjuangan hidup manusia terhadap alam danjaman.

Konsep Ki Hadjar Dewantara mengenai pendidikan sebagai usaha kebudayaan ini selaras juga dengan filsafat progresivisme yang mengatakan bahwa kemajuan atau progress menjadi inti perkataan progresivisme maka beberapa ilmu pengetahuan yang mampu menumbuhkan kemajuan merupakan bagian-bagian utama dari kebudayaan. Antara filsafat Ki Hajar dengan progresivisme terdapat perbedaan, jika dalam progresivisme ilmu pengetahuan yang mampu menumbuhkan kemajuan adalah ilmu hayat, antropologi, psikologi dan ilmu alam, sedangkan dalam konsep Ki Hadjar Dewantara di samping ilmu yang umum, kesenian merupakan bagian yang penting dalam kurikulum pendidikan.

\section{Pandangan Ki Hadjar Dewantara tentang pengetahuan}

Menurut penulis, pandangan pengetahuan bagi Ki Hadjar Dewantara adalah bagaimana anak didik memperoleh pengetahuan. Sesuai dengan teori Ki Hadjar Dewantara tentang Tri No untuk prasekolah dan Tri Nga untuk Sekolah Dasar ke atas, berarti pengetahuan didapatkan anak didik dengan nonton (cognitive). Nonton di sini menonton secara pasif dengan segenap panca indera, selanjutnya niteni (affective) adalah menandai, mempelajari, mencermati apa yang ditangkap panca indera kemudian nirokke (psikomotor) yaitu menirukan yang positif untuk bekal menghadapi perkembangan anak. (Dwiarso, 2010: 1). Pada tingkat Sekolah Dasar ke atas, pengetahuan didapatkan dengan Tri Nga, yaitu ngerti (cognitive) dengan akal, ngrasa (affective), yaitu merespon, menghargai, menjunjung nilai-nilai dan nglakoni (psychomotor) yaitu bertindak secara terpimpin.

Bila dipandang dari progresivisme maka pandangan Ki Hadjar Dewantara tentang pengetahuan hanya sebagian yang memiliki kesesuaian, karena progresivisme lebih menekankan pada pandangan pragmatisme yang bersifat empirik. Menurut pragmatisme, proses me- 
ngetahui adalah fakta yang ditangkap oleh pengalaman yaitu panca indera. Menurut penulis, pandangan Ki Hadjar Dewantara tentang pengetahuan lebih lengkap karena pengetahuan itu adalah hasil cipta, rasa dan karsa.

\section{Pandangan Ki Hadjar Dewantara tentang belajar}

Pandangan Ki Hadjar Dewantara tentang belajar nampak pada konsep mengenai Tri Pusat Pendidikan, bahwa anak didik tidak semata-mata hanya belajar di sekolah tetapi juga dalam keluarga dan masyarakat (dalam alam pemuda). Pendidikan alam keluarga akan mendidik anak-anak dengan sebaik mungkin yang meliputi jasmani dan rohani. Keadaan keluarga sangat mempengaruhi perilaku pendidikan, terutama tolong-menolong dalam keluarga, menjaga saudara yang sakit, kebersamaan dalam menjaga kebersihan, kesehatan, kedamaian dan kebersamaan dalam berbagai persoalan yang sangat diupayakan dalam keluarga.

Di dalam alam keluarga orangtua dapat menanamkan segala benih kebatinan yang sesuai dengan kebatinannya sendiri, ke dalam jiwa anak. Ini adalah hak orangtua yang paling utama dan tidak boleh dicegah orang lain, jadi orangtua berperan sebagai guru (pemimpin laku adab), sebagai pengajar (pemimpin kecerdasan serta pemberi ilmu pengetahuan) dan menjadi contoh laku sosial. Selanjutnya dalam alam perguruan, institusi ini berkewajiban mengusahakan kecerdasan pikiran (perkembangan intelektual) serta memberikan ilmu pengetahuan. Menurut Ki Hadjar Dewantara, memaparkan agar pendidikan alam perguruan tidak hanya mementingkan intelek sehingga bersifat zakelijk atau tak berjiwa, yang akan berpengaruh kuat terhadap tumbuhnya egoisme dan materialism, maka Ki Hadjar Dewantara sangat menggarisbawahi pendapat Pestalozzi yang mengatakan bahwa pendidikan intelektual harus disesuaikan dengan kodrat alam dan pendidikan keluarga.

Kesempurnaan pendidikan dalam masyarakat akan terwujud apabila orang-orang yang berkepentingan, yaitu orangtua, tokoh- 
tokoh masyarakat, guru-guru dengan anak atau pemuda, bersatu paham, misal dalam bidang agama, bidang politik, dalam kebangsaan, sehingga sistem Tri Pusat Pendidikan itu akan tercapai. Terwujudnya Tri Pusat Pendidikan akan melahirkan calon-calon pemimpin bangsa ini yang berkarakter Ing Ngarsa Sung Tulodho, Ing Madya Mangun Karsa dan Tut Wuri Handayani. Para pemimpin yang diidealkan Ki Hadjar Dewantara ini di masa depan akan menghasilkan pemimpin yang tangguh karena merupakan pemimpin yang disiplin terhadap dirinya sendiri maupun terhadap lingkungan masyarakatnya.

Pemimpin berkarakter Ing Ngarsa Sung Tulodho, Ing Madya Mangun Karsa dan Tut Wuri Handayani tidak akan melakukan penyalahgunaan wewenang atau kekuasaan, tidak akan melakukan manipulasi keuangan atau korupsi, dan tidak akan melanggar kesusilaan. Bila pandangan Ki Hadjar Dewantara tentang belajar dibandingkan dengan pandangan progresivisme maka tidak jauh berbeda. Hal ini karena salah satu dasar yang digunakan dalam sistem among, yaitu kemerdekaan, secara paedagogis merupakan syarat untuk membantu perkembangan segala potensi anak didik tanpa tekanan dan hambatan. Dengan demikian akan memungkinkan perkembangan pribadi yang kuat pada anak didik.

Anak didik dengan bawaan kodratnya diberikan kebebasan atau kemerdekaan untuk mengatasi sendiri masalah-masalah yang dihadapi. Jadi pendidik hanya melakukan Tut Wuri Handayani, kecuali masalah-masalah yang dihadapi anak didik tersebut membahayakan dirinya sendiri, baru pendidik mengambil alih tindakan terhadap permasalahan-permasalahan tersebut. Konsep Ki Hadjar Dewantara mengenai belajar tersebut bila ditinjau dari filsafat progesivisme tidaklah bertentangan, karena progresivisme mempunyai konsep yang didasarkan pada kepercayaan bahwa manusia mempunyai kemampuan-kemampuan yang wajar dan dapat menghadapi serta mengatasi masalah-masalah yang bersifat menekan atau mengancam manusia itu sendiri (Barnadib, 1982: 28). Satu hal yang agak berbeda yaitu pada sistem Tut Wuri Handayani, pandangan Ki Hadjar Dewantara berbeda dengan progresivisme, karena apabila kebebasan anak didik dalam 
menyelesaikan masalah-masalah ternyata mengancam anak didik itu sendiri dalam arti berbuat salah maka pendidik boleh mengambil permasalahan-permasalahan tersebut.

\section{KONSEP PENDIDIKAN KI HADJAR DEWANTARA DALAM TINJAUAN FILSAFAT PENDIDIKAN ESENSIALISME}

Esensialisme mempunyai tinjauan mengenai kebudayaan dan pendidikan yang berbeda dengan progresivisme, jika progresivisme menganggap bahwa banyak hal itu mempunyai sifat yang serba fleksibel dan nilai-nilai itu berubah dan berkembang, maka esensialisme menganggap bahwa dasar pijak semacam ini kurang tepat. Dalam pendidikan, fleksibilitas dalam segala bentuk dapat menjadi sumber timbulnya pandangan yang berubah-ubah, pelaksanaan yang kurang stabil dan tidak menentu (Barnadib, 1982: 38). Berikut adalah penjelasan konsep-konsep pendidikan Ki Hadjar Dewantara dalam perspektif Esensialisme.

\section{Pandangan Ki Hadjar Dewantara tentang pendidikan}

Menurut Ki Hadjar Dewantara, pendidikan merupakan salah satu usaha pokok untuk memberikan nilai-nilai kebatinan yang ada dalam hidup rakyat yang berkebudayaan kepada tiap-tiap turunan baru (penyerahan kultur), tidak hanya berupa "pemeliharaan" akan tetapi juga dengan maksud "memajukan" serta "memperkembangkan" kebudayaan, menuju ke arah keseluruhan hidup kemanusiaan (Dewantara, 2011: 344). Kebudayaan yang dimaksud adalah kebudayaan bangsa sendiri mulai dari Taman Indria, anak-anak diajarkan membuat pekerjaan tangan, misalnya: topi (makuto), wayang, bungkus ketupat, atau barang-barang hiasan dengan bahan dari rumput atau lidi, bunga dan sebagainya. Hal ini dimaksudkan agar anak jangan sampai hidup terpisah dengan masyarakatnya (Dewantara, 2011:276).

Metode permainan yang masih terdapat di desa-desa dimaksudkan untuk melatih ketangkasan, melihat, mendengar dan bertindak sebagai latihan panca indera. Banyak permainan anak-anak yang berupa tarian, sandiwara-sandiwara yang amat sederhana, tetapi cukup 
mengandung bahan-bahan untuk pendidikan, misalnya seni suara, tari dan drama. Drama dari cerita-cerita rakyat seperti Timun Emas, Bawang Putih, Jaka Kendil maupun cerita-cerita Wayang Purwa. Untuk anak-anak yang sudah besar, misalnya Taman Dewasa atau Sekolah Menengah Pertama dan Taman Madya atau Sekolah Menengah Atas, akan diberikan pelajaran olah gending. Hal tersebut dimaksudkan untuk memperkuat dan memperdalam rasa kebangsaan.

Tari Serimpi dan tari Bedoyo diberikan kepada anak didik karena merupakan kesenian yang amat indah yang mengandung rasa kebatinan, rasa kesucian dan rasa keindahan. Gending-gending Keraton jaman dulu diwajibkan untuk dipelajari, juga Tari Serimpi. Di samping Tari Serimpi juga diajarkan sandiwara atau drama yang dalam istilah Jawa disebut tonil, misalnya: Srandul, Reog, Kethoprak, Wayang, Langendriyan, Langen Wanara, Langen Asmara Suci (Dewantara, 2011:347-348).

Frobel dan Montessori adalah tokoh-tokoh pendidikan anakanak yang banyak berpengaruh pada pandangan-pandangan pendidikan Ki Hadjar Dewantara. Ki Hadjar Dewantara mengatakan bahwa kesenian yang dipakai sebagai alat pendidikan dalam Taman Siswa tetap bermaksud mempengaruhi perkembangan jiwa anak-anak ke arah keindahan pada khususnya, namun keindahan di dalam rangkaiannya dengan keluhuran dan kehalusan sehingga layak bagi hidup manusia yang beradab dan berbudaya. Jadi ada perkembangan jiwa anak "dari natur ke kultur" (Dewantara, 2011:353).

Konsep pendidikan Ki Hadjar Dewantara dibandingkan dengan filsafat pendidikan esensialisme sangat mirip, karena esensialisme berpendapat bahwa pendidikan harus didasarkan kepada nilai-nilai kebudayaan yang telah ada sejak awal peradaban umat manusia. Kebudayaan yang diwariskan merupakan kebudayaan yang telah teruji oleh segala jaman, kondisi dan sejarah (Noor Syam, 1983: 260).

Nilai-nilai kebudayaan bukanlah nilai-nilai yang statis tetapi juga mengalami kemajuan. Ki Hadjar Dewantara mengatakan hendaknya usaha kemajuan ditempuh melalui petunjuk "Trikon", yaitu: kontinyu dengan alam masyarakat Indonesia sendiri. Artinya, secara 
kontinyu kebudayaan harus diestafetkan atau diberikan kepada generasi penerus secara terus-menerus. Kemudian konvergen dengan budaya luar. Artinya, penerima nilai-nilai budaya dari luar dengan selektif dan adaptif dan akhirnya bersatu dengan alam universal, dalam persatuan yang konsentris yaitu bersatu namun tetap mempunyai kepribadian sendiri.

Jadi dapat disimpulkan bahwa kebudayaan Indonesia adalah kebudayaan yang maju tetapi tetap berkepribadian Indonesia (Dewantara, 1994: 371). Nilai-nilai budaya yang digunakan Ki Hadjar Dewantara dalam pendidikan adalah nilai budaya yang ada sejak beliau dilahirkan, yaitu pada masa Adipati Paku Alam III tahun 1889, jadi nilai-nilai budaya sekitar abad ke-18 dan 19. Sedang filsafat pendidikan esensialisme didasarkan pada jaman Renaisans yang muncul sekitar abad ke-15 dan 16.

\section{Pandangan Ki Hadjar Dewantara tentang pengetahuan}

Salah satu dasar dalam sistem among Ki Hadjar Dewantara adalah kodrat alam, sebagai syarat untuk mencapai kemajuan dengan secepat-cepatnya dan sebaik-baiknya. Kodrat alam sebagai manifestasi kekuatan Tuhan Yang Maha Esa mengandung arti bahwa pada hakikatnya manusia sebagai makhluk Tuhan adalah satu dengan alam semesta, dengan demikian manusia wajib tunduk kepada hukumhukum alam dan wajib menyatukan atau menyelaraskan dirinya dengan kodrat alam. Penyesuaian diri dengan alam tersebut merupakan proses pembudayaan manusia.

Pernyataan asas Taman Siswa (beginselverklaring), sebagai reaksi terhadap sistem pendidikan yang memaksakan kultur asing sebagai landasannya sehingga proses dan hasilnya tidak sesuai dengan kodrat anak Indonesia, menegaskan, "Yang kita pakai sebagai alat pendidikan, yaitu pemeliharaan dengan sebesar-besar perhatian (toewijdende zorg) untuk mendapatkan tumbuh kembangnya kehidupan anak lahir batin, menurut kodratnya sendiri." Jika kultur asing dipaksakan, maka nilai-nilai yang akan dikembangkan pasti juga akan menyimpang dari nilai-nilai budaya bangsanya. Hal demikian tidak mungkin digunakan 
untuk keperluan membentuk watak dan kepribadian bangsa. Anakanak tersebut akan terasing dari kehidupan bangsanya dan tidak akan peka terhadap aspirasi dan penderitaan rakyatnya. Dengan demikian maka dasar kodrat alam digunakan dalam arti edukatif dan dalam kaitannya dengan proses belajar-mengajar (Soeratman, 1983/1984: 9$10)$.

Ditinjau dari filsafat pendidikan esensialisme terutama yang didukung oleh idealisme modern bahwa di balik dunia fenomenal ini ada jiwa yang tak terbatas, yaitu Tuhan, yang merupakan pencipta adanya kosmos. Manusia sebagai makhluk yang berpikir berada dalam lingkungan kekuasaan Tuhan. Manusia bila mau menguji dan menyelidiki ide-ide serta gagasan-gagasannya, maka manusia akan dapat mencapai kebenaran yang sumbernya adalah Tuhan sendiri (Barnadib, 1982:39).

Idealisme modern mengemukakan tinjauan yang seperti itu dalam rangka memberikan jalan bagi perkembangan baru dalam kebudayaan dan ilmu pengetahuan. Teori Leibniz tentang monade menjelaskan bahwa sifat-sifat monade mencerminkan alam semesta, sesuai dengan apa yang tercipta oleh Tuhan. Hal ini berarti bahwa meskipun atribut (sifat-sifat) ini terbatas, ia mempunyai kemungkinan untuk menuju kesempurnaan dengan cara sendiri.

Mengenai pandangan Ki Hadjar Dewantara tentang pengetahuan maupun belajar, memang tidak secara rinci dipisahkan dari pandangan pendidikan, tetapi dapat kiranya ditunjukkan bahwa proses belajar untuk mendapatkan pengetahuan adalah penggunaan panca indera yang kemudian diolah oleh intelek, selanjutnya dipraktekkan dalam kehidupan yang merupakan kegiatan psikomotorik.

Pandangan Ki Hadjar Dewantara tersebut bila ditinjau dari filsafat pendidikan esensialisme adalah mirip. Landasan berpikir esensialisme mengatakan bahwa belajar dapat didefinisikan sebagai jiwa yang berkembang pada sendirinya sebagai substansi spiritual jiwa membina dan menciptakan diri sendiri (Barnadib, 1982: 55). Tinjauan filsafat pendidikan esensialisme tentang pandangan Ki Hadjar Dewantara mengenai pengetahuan dan belajar dapat dijelaskan sebagai berikut. 
Pandangan esensialisme mengenai pengetahuan, yang dikatakan sebagai asosianisme, mengatakan bahwa gagasan atau isi jiwa itu terbentuk dari asosiasi unsur-unsur yang berupa kesan-kesan yang berasal dari pengamatan. Kesan-kesan tersebut disebut tanggapan yang dapat diumpamakan sebagai atom-atom jiwa (Barnadib, 1982: 49), sedangkan behaviorisme sebagai pendukung esensialisme mengatakan bahwa suatu penghayatan kejiwaan terdiri dari proses-proses yang paling sederhana yang terdiri dari rangsang (stimulus) dari luar, yang disambut dengan tanggapan tertentu (response). Rangsang dan tanggapan menjadi satu kesatuan (sarbon). Dalam proses berikutnya, peristiwa kejiwaan merupakan saling-hubungan antar unsur-unsur tersebut dalam berbagai cara dan bentuk (associanism). Koneksionisme sebagai gerakan ketiga mengatakan bahwa manusia dalam hidupnya selalu membentuk tata jawaban dengan jalan memperkuat dan memperlemah hubungan antara Stimulus (S) dan response (R). Untuk ini dikembangkan kaidah mengenai belajar dan mengenai pengetahuan yang dimiliki seseorang (Barnadib, 1982: 49).

Jadi pandangan Ki Hadjar Dewantara dengan esensialisme tentang belajar tidak bertentangan karena keduanya mengatakan bahwa untuk mendapatkan pengetahuan digunakan panca indera kemudian diolah oleh akal sehingga gambaranjiwa (batin) terbentuk.

\section{SUMBANGAN PEMIKIRAN KI HADJAR DEWANTARA BAGI PENDIDIKAN INDONESIA}

Sistem Paguron menurut pandangan Ki Hadjar Dewantara merupakan suatu sistem pendidikan nasional karena sistem pendidikan ini berorientasi pada nilai-nilai kultural, hidup kebangsaan serta kemasyarakatan Indonesia. Gagasan paguron mencakup pengertian bahwa paguron sebagai tri pusat pendidikan, yaitu sebagai tempat guru, sebagai tempat belajar, dan sebagai tempat pendidikan dalam masyarakat.

Berdasarkan pengamatan secara langsung dalam kehidupan masyarakat saat ini sebenarnya banyak menjumpai pendidikan pada pesantren modern yang berkembang di kota-kota besar maupun di 
desa-desa di Indonesia. Penulis ingin menunjukkan bahwa konsep pendidikan Ki Hadjar Dewantara yang dikenal dengan sistem paguron benar-benar diterapkan dalam dunia pendidikan di luar Taman Siswa. Hal ini juga diungkapkan oleh Tyasno Sudarto, seorang tokoh TNI.

"Kendati ajaran militer itu keras, toh tidak ada unsur pemaksaan. Selain itu, saya melihat sistem padepokan yang diajarkan Ki Hadjar Dewantara ada juga dalam militer. Sebab, banyak prajurit tinggal di asrama. Antara pimpinan dan anak buah tinggal dalam satu lingkungan, sehingga pimpinan, pamong, atau guru bisa mengikuti perkembangan dan proses pendidikan anak. Saya sudah lama mengagumi beliau, terutama ajaran-ajarannya. Ternyata, konsep ing ngarsa sung tuladha, ing madya mangun karsa, dan tutwuri handayani sangat klop dalam dunia militer (Sudarto, 2008: 78).

Gagasan Ki Hadjar Dewantara menciptakan pendidikan berbentuk pondok asrama terwujud secara fisik melalui pembangunan SMA Taruna Nusantara di Magelang tahun 1990. Penjabaran sistem pondok ini tampak dalam bentuk kerjasama Taman Siswa dengan ABRI ketika sepakat mendirikan SMA Taruna Nusantara. Peresmian sekolah itu dilakukan oleh Try Soetrisno yang ketika itu menjabat sebagai Panglima ABRI. Inilah babak baru bagi Taman Siswa yang menerima kepercayaan pihak ABRI. Latar belakang terjalinnya kerjasama ini diprakarsai oleh LB Moerdani.

Ketika memaparkan lintasan sejarah Taman Siswa, H. Moesman Wiryosentono menuliskan, "20 Mei 1987 di Pendapa Agung Taman Siswa LB Moerdani melontarkan gagasan agar Taman Siswa menyelenggarakan pendidikan untuk mempersiapkan calon kader bangsa, yang diperlukan bangsa Indonesia di masa datang. Pada saat itu diusulkan bentuk sekolah tingkat menengah atas. Prakarsa ini ditanggapi positif oleh Majelis Luhur sebagai pimpinan pusat Taman Siswa dan berkembang menjadi kerjasama dari pihak ABRI maka terwujudlah SMA Taruna Nusantara di Magelang. Tugas pokok dalam kerjasama itu, pihak ABRI mempersiapkan dan menyediakan perangkat 
keras, sedangkan Taman Siswa bertanggung jawab terhadap persiapan penyediaan perangkat lunaknya. SMA Taruna Nusantara adalah wujud nyata kerjasama sistem paguron dengan pendidikan militer, namun tidak untuk menciptakan militerisme. Konsep kedisiplinan dan sistem asrama bisa saling mengisi dalam menghadapi tantangan jaman. Dilihat dari konsep Taman Siswa, SMA Taruna Nusantara merupakan konsep perguruan dari Ki Hadjar Dewantara dalam skala nasional.

Sekolah ini menggunakan asrama sebagai sistem pendidikannya, sehingga semua tinggal bersama-sama satu kompleks dengan para guru, pamong, dan pengurus sekolah, membentuk suatu masyarakat kekeluargaan dalam kebersamaan yang tinggi. Menurut Tyasno Sudarto, SMA Taruna Nusantara menggunakan sistem Tri Pusat, yakni memadukan tiga lingkungan pendidikan, yaitu pendidikan sekolah, pendidikan keluarga, dan pendidikan masyarakat. Selain itu metode among diterapkan dengan Tutwuri Handayani sebagai dasar pengajaran, pengasuhan, dan pelatihannya (Sudarto, 2008: 80).

Pendidikan militer yang memiliki citra kedisiplinan pada kenyataannya sangat relevan dengan ajaran pendidikan Ki Hadjar Dewantara di Taman Siswa, yaitu memberikan kebebasan bagi para individu untuk berkembang sesuai dengan kodrat alam. Ki Hadjar Dewantara juga pernah mengatakan bahwa kita bisa hidup di alam masyarakat yang tertib dan damai. Artinya, kebebasan tidak boleh lepas dari ketertiban, karena ketertiban akan melahirkan kedamaian. Kalau tidak tertib, pasti tidak akan ada kedamaian, oleh sebab itu, kalau kita semua masyarakat tertib dipastikan karena masyarakatnya disiplin, jadi semua itu sangat relevan dengan apa yang terdapat di dalam pendidikan militer. Antara pendidikan militer dan pendidikan di Taman Siswa tidak ada perbedaan, sama-sama menciptakan tujuan yang positif, yaitu tertib dan damai.

Asas Taman Siswa mengatakan bahwa hak seseorang akan mengatur dirinya sendiri dengan mengingat tertibnya persatuan di dalam kehidupan umum. Tertib dan damai itulah yang menjadi tujuan setinggi-tingginya. Tidak ada kedamaian bila tidak ada ketertiban. Sekarang ini masyarakat masih belum mengerti dan memahami apa yang di- 
tanamkan sistem pendidikan Taman Siswa di era globalisasi. Sebenarnya, Taman Siswa bukanlah sekedar sekolah, namun sebuah badan perjuangan, kebudayaan, dan pembangunan masyarakat yang berdasarkan kiprah pendidikan dalam arti luas. Taman Siswa tidak pernah memisahkan pendidikan nasional dengan masalah-masalah yang ada di dalam masalah kebangsaan. Sebagai badan perjuangan, Taman Siswa sangat peduli dengan masalah yang dialami rakyat dan masyarakat, serta selalu berpartisipasi secara efektif membangun politik kenegaraan, ekonomi, budaya, dan pertahanan keamanan masyarakat.

Melihat berbagai macam pola pendidikan yang berbeda satu dengan lainnya, Taman Siswa tetap berkeyakinan bahwa sistem pendidikan harus kembali ke sistem pendidikan yang sudah dijabarkan oleh Ki Hadjar Dewantara walaupun harus disesuaikan dengan perkembangan jaman dan globalisasi. Apa yang ditanamkan Ki Hadjar Dewantara sesungguhnya sudah menjadi dasar pemikiran yang terusmenerus harus disosialisasikan kepada anak didik dan masyarakat.

Pengaruh budaya luar tidak bisa ditolak, jika terdapat hal yang baik, bisa diambil dijadikan ajaran baru, sedang yang jelek dibuang. Semuanya harus sesuai dengan jati diri bangsa dan kemudian dikembangkan sebagai bagian ajaran baru. Filter dari semuanya adalah kesadaran akan kodrat alam bahwa manusia mempunyai kebiasaan-kebiasaan hidup yang berbeda-beda antara satu bangsa dengan bangsa yang lain. Dipilihnya sistem paguron dari Ki Hadjar Dewantara karena sistem pondok yang dimaksudkan Ki Hadjar Dewantara besar sekali faedahnya.

Faedah pertama, membuat murahnya belanja. Seorang yang hidup paguron seharusnya berani hidup sederhana. Menurut Prof. Van Vollenhoven dalam tulisannya, The Old Glory, yang dikutip Prof Dr. Sukanto, Ki Hadjar Dewantara seorang di antara sedikit orang yang memiliki kemampuan untuk memberikan pengajaran berdasarkan kekuatan sendiri, yang lebih murah untuk masyarakat, seratus kali lebih berguna dan lebih baik daripada pengajaran yang berdasarkan Barat. Dengan demikian, sistem paguron adalah sistem nasional yang sesuai dengan kepribadian bangsa, murah dan sangat baik hasilnya.

Faedah kedua, guru-guru dan murid hidup bersama tiap hari. 
Siang dan malam berkumpul dan bergaul bersama menurut pedagogik yang hidup, yakni dengan contoh-contoh keteladanan, terutama dalam suasana kehidupan keluarga sehari-hari yang nyata dan baik. Cara seperti ini menjadikan anak-anak didik tidak terpisahkan dengan orangtuanya, baik lahir maupun batin.

Anak-anak sehari-hari terus merasa anak rakyat, terus hidup dalam alam kemanusiaan. Berhubungan dengan pengajaran, anakanak harus berhubungan dengan kondisi saat ini, selalu berhubungan dengan barang-barang nyata dan harus bermaksud mendidik lahir batin, mematangkan anak-anak untuk hidup sebagai manusia utama dalam dunia raya (Sudarto, 2008: 83).

\section{SIMPULAN}

Berdasarkan uraian di atas, dapat disimpulkan hal-hal sebagai berikut:

1) Hakikat pendidikan menurut Ki Hadjar Dewantara adalah memasukkan kebudayaan ke dalam diri anak dan memasukkan anak ke dalam kebudayaan supaya anak menjadi makhluk yang insani.

2) Filsafat pendidikan Ki Hadjar Dewantara disebut filsafat pendidikan among yang di dalamnya merupakan konvergensi dari filsafat progresivisme tentang kemampuan kodrati anak didik untuk mengatasi persoalan-persoalan yang dihadapi dengan memberikan kebebasan berpikir seluas-luasnya. Di samping itu digunakan kebudayaan yang sudah teruji oleh waktu, menurut esensialisme, sebagai dasar pendidikan anak untuk pencapaian tujuannya. Khusus mengenai kebebasan berpikir, menurut Ki Hadjar Dewantara, bila membahayakan anak didik berbuat salah maka akan diambil alih pamongnya (Tutwuri Handayani). Selain itu Ki Hadjar Dewantara menggunakan kebudayaan asli Indonesia, sedangkan nilai-nilai dari Barat diambil secara selektif adaptatif sesuai dengan teori trikon (kontinyuitas, konvergen dan konsentris).

3. Kontribusi filsafat pendidikan Ki Hadjar Dewantara terhadap pendidikan di Indonesia adalah dengan munculnya model-model 
74 Jurnal Filsafat, Vol. 25, No. 1, Februari 2015

pendidikan pesantren modern yang sering dikenal dengan MBS (Modern Boarding School). Namun secara jelas adalah dibangunnya SMA Taruna Nusantara yang benar-benar menerapkan sistem paguron dari Ki Hadjar Dewantara.

\section{DAFTAR PUSTAKA}

Barnadib, Imam, 1982, Filsafat Pendidikan, Pengantar Mengenai Sistem dan Metode Fakultas Ilmu Pendidikan, IKIP Yogyakarta.

Dewantara, Ki Hadjar, 1994, Kebudayaan, Majelis Luhur Persatuan Taman Siswa, Yogyakarta. 2011, Bagian Pertama Pendidikan, Majelis Luhur Persatuan, Yogyakarta.

Dwiarso, Priyo, 2010, Napak Tilas Ajaran Ki Hadjar Dewantara, Majelis Luhur Pesatuan, Yogyakarta.

Ki Suratman, 1987, Tugas Kita Sebagai Pamong Taman Siswa, Majelis Luhur Yogyakarta.

Noor Syam, Mohammad, 1983, Filsafat Pendidikan dan Dasar Filsafat Pendidikan Pancasila, Usaha Nasional, Surabaya.

Saksono, Gatut Ign, 2010, Pendidikan Yang Memerdekakan Siswa, Diandra Primamitra Media, Yogyakarta.

Soeratman, Darsiti, 1983/1984, Ki Hadjar Dewantara, Proyek Inventarisasi dan dokumentasi Sejarah Nasional, Direktorat Sejarah dan Nilai Tradisional, Departemen Pendidikan dan Kebudayaan RI, Jakarta.

Sudarto, Tyasno, 2008, Garis Simpul Karya Ki Hadjar Dewantara, Galang Press, Yogyakarta.

Sutiyono, 2010, "Pendidikan Seni Sebagai Basis Pendidikan Karakter Multikulturalis" dalam Cakrawala Pendidikan Jurnal Ilmiah Pendidikan, No. XXIX. Edisi Khusus Dies Natalis UNY, Ikatan Sarjana Pendidikan Indonesia D.I. Yogyakarta. 